\title{
Economic Impact of Organic Farming; Cases from the Farmers of Nepal
}

\author{
Raj Kumar Banjara \\ PhD Scholar, Mewar University, Rajasthan, India
}

Meena Poudel, PhD

\begin{abstract}
Economic status of various social groups and families is a key foundation for a sustainable development of that particular society. For Nepal, agriculture is still a key base of economic growth and national development. Practice of Organic farming as an emerging practice among Nepalese farmers because of its socio-economic benefit in long term. Expected benefits of organic farming systems are not yet visible in Nepalese agricultural practices because of the lack of study on it. However, there is growing interest in the literature that adoption of such systems produces multiple environmental, social, and financial benefits that can contribute in solving pressing agricultural problems in Nepal. The main objective of this study was to focus in exploring economic impact of organic farming in livelihoods of farmers of Nepal in general. This study was conducted in Kathmandu, Lalitpur, Bhaktpur and Dhading district. Purposive sampling technique was applied for this exploratory research and structured questionnaire was administered to carry out this research. . Preliminary findings showed that the average annual income of Nepalese farmer was better than the average income of those people who do physically labour work in private and public sector. Economically, farmers were found satisfied and encouraged to expand their organic business. There was significant difference in the level of income between the study districts. Because of the market access and quality and quantity of production made the significant difference in the level of income. There was need of consumers' awareness program so that farmers will get the good prize of their production. Besides that government should be responsible to manage the organic market.
\end{abstract}

KEYWORD: Economic, Farming, Impact, Organic, Nepal

\section{INTRODUCTION}

Development approaches of Nepal are predominantly based in subsistence Agriculture. According to the Agriculture and Food Security report of USAID, Over $70 \%$ of Nepal's population works in the agriculture sector (USAID, 2015), therefore Nepal is still understood as an agricultural country. This claim has also been evidenced by the Statistical Information on Nepalese Agriculture- 2011/2012 that reported by stating in total agriculture has 35\% contribution in GDP of Nepal (Agri statistics Section, 2011/2012). It is believed that civilization began with subsistence agriculture. Not only did villages, towns and cities begin to flourish, but so did knowledge, the arts and the technological sciences. And for most of history, society's connection to the land was intimate. Human communities, no matter how sophisticated, could not ignore the importance of agriculture. To be far from dependable sources of food was to risk malnutrition and starvation (One Country, 2013).

This article discusses on organic farming that is essentially traditional farming based on knowledge and techniques gathered over thousands of years of agriculture practices prior to the chemical farming revolution. Vegetable farming is the traditional farming system practiced 
by farmers in rural village. Although the production is less in large areas but because of higher selling price has compensate with it. In that cost of production is less than of conventional system because the cost of fertilizer is not required. Farmers use cow dung, chicken manure, compost, application of wood ash, cattle urine for top dressing and incorporation of credible parts of vegetable into the soil as organic manure produced in an around by them self. Farmers situated in the hills not only produce vegetables for domestic consumption, but also for sale in the market for cash income. By which they educate their children, increase their land (Anjana Malla Pradhan, 2015, p. 924). There is no precise beginning to organic agriculture. Some people say that all agriculture before the 20th century was organic, but in fact organic agriculture is much more than the absence of modern fertilizers and pesticides. In the first half of the 20th century several people began to question the movement towards intensification and monoculture in agriculture and to look for holistic, ecological, systems approaches that would preserve the quality of the land. Some of the best known of these figures are Sir Albert Howard in India and Britain, Rudolf Steiner in Germany, and I.J. Rodale in the US. Many people credit Sir Alfred Howard with being the founder of organic agriculture and look to his book, An Agricultural Testament, as laying the groundwork for the field (University of Wisconsin, 2014).

Organic farming is known to be environmentally sustainable, but can it be economically sustainable, as well? The answer is yes, according to new research in the Sept.-Oct. issue of Agronomy Journal. In an analysis of 18 years of crop yield and farm management data from a long-term University of Minnesota trial, an organic crop rotation was consistently more profitable and carried less risk of low returns than conventional corn and soybean production, even when organic prime premiums were cut by half (Delbridge, Coulter, King, Sheaffer, \& Wyse, 2011). Organic agriculture can contribute to uplift the economic status of farmers because of the lower cost production of organic farms than conventional farms.

According to the Organic Field Crop Handbook of Canadian Organic Growers, Organic farms have lower costs of production than conventional farms, with much less emphasis on purchased inputs. Synthetic fertilizer and pesticide purchases are eliminated, and costs of purchased feed, veterinary bills, and replacement livestock are lower. In addition, organic farmers have lower fixed (overhead) costs for depreciation and interest charges attached to capital inputs, such as machinery and equipment. On balance, input costs are lower on organic farms (Canadian Organic Growers, 2011). On the basis of analysis of cost and benefit of farming, it can be assumed that organic farming has significant contribution in the economic uplift of farmers. In relation to the findings of previous study and experiences shared by the organic farmers, the study was set the objective to identify the economic impact of organic agriculture on farmers after involving in organic farming. The farmers were asked about the changes of their social status as well as economic status after involving in organic agriculture.

\section{METHODS}

The study was based on the mixed method; quantitative and qualitative data were collected. Quantitative data was supported by the qualitative data to support the analysis of quantitative findings. The study was descriptive as well as exploratory design. Data was collected from the 578 farmers of Kathmandu, Lalitpur, Bhaktpur and Dhading district of Nepal. Because of the limited numbers of organic farmers, the study had adopted the purposive sampling technique to select the farmers and consent was sought in advance. Structured questionnaire survey was done among the organic farmers to collect the quantitative data and semi-structured interview checklist was used to collect the qualitative data from the organic farmers and concerned expert of organic agriculture. Quantitative data was analysed by using the statistical software and qualitative data was analysed manually in narrative form. 


\section{RESULT AND DISCUSSION}

The study was conducted among the 578 organic farmers where $66.9 \%$ (392) male followed by $33.1 \%$ (194) female participated in the study. The district wise data showed that in total 8.5\% (50) organic farmers from Kathmandu, 28.3\% (166) from Lalitpur, 19.1\% (112) from Bhaktpur and 44\% (258) from the Dhading district participate in the study. Minimum 15 to maximum 85 years old people were involved in the organic agriculture. There were $25.9 \%(152)$ farmers illiterate followed by 30.5\% (179) had primary level education, 9.7\% (57) had lower secondary level, 14.5\% (85) had secondary level, 10.9\% (64) had intermediate level, 6.3\% (37) had Bachelor level and 2\% (12) had masters and above level education. In total, 27.3\% (158) said that they were doing the Coffee, 1\% (6) was doing Tea, 80.3\% (464) was doing Vegetable, 17.1\% (99) was doing Fruits, 18.2\% (105) was doing Spices, 2.6\% (15) was doing meat items (meat/fish/poultry), 28.7\% (166) were doing the livestock, 16.1\% (93) were doing milk and dairy products and $7.1 \%$ (41) were doing others.

\section{Total organic agricultural land}

The data collected from the farmers interviewed in this research, it was found that organic agriculture was doing in minimum 1 ropani ( 0.0509 hectare) to 55 ropani (2.799 hectare) lands. In average, 1 household $=6.2656$ (0.31 hectare) land was cultivated for the organic agriculture. The organic farmers shared that the land was not adequate for them to produce the organic items as the demand of market. The study districts are located in the hilly areas of Nepal so geographically also agricultural land size is not enough. On the other hand, because of the increasing size of population and plotting of land for housing also made problem to get the appropriate land for organic agriculture. Farmers also shared that they could not do the organic agriculture near to the road side because of the polluted dust and air pollution by transportation, made the disturbance in quality and quantity of production so they had to choose the land of remote areas which had problem of easy transportation and market access.

Table 1: Total organic agricultural land (unit in Ropani where 1 Ropani=0.0509 hectare Descriptive Statistics

\begin{tabular}{|l|l|l|l|l|l|}
\hline & $\mathrm{N}$ & Minimum & Maximum & Mean & Std. Deviation \\
\hline $\begin{array}{l}\text { Land size for organic } \\
\text { agriculture }\end{array}$ & 578 & 1.00 & 55.00 & 6.2656 & 6.61546 \\
\hline Valid N (listwise) & 578 & & & & \\
\hline
\end{tabular}

Source: Field Survey, 2015

As the survey report of FiBL - IFAOAM 2014 reported that there was 10273 Hectares land covered by the organic farming in Nepal which was increased by 18.1\% from 2011 (8697 ha.) to 2012. The total organic agricultural land of Nepal shares $0.12 \%$ of world organic agricultural land (Helga Willer, 2014, p. 40).

The USDA 2012 Census of Agriculture ranks Wisconsin second in the nation for the total number of organic farms, with 1,180 farms. This represents approximately $8 \%$ of the organic farms in the U.S. According to data from the USDA National Organic Program, the number of certified organic farms in Wisconsin grew 77 percent from 2005 to 2013 (Carusi, Gurda, McNair, Pfeiffer, \& Silva, 2015, p. III). Wisconsin is fourth in the country in terms of organic commodity sales, valued at $\$ 122$ million. This accounts for one percent of Wisconsin's total agricultural sales and about four percent of the nation's organic sales. Wisconsin's lower ranking in organic sales versus organic farm numbers (where it ranks second) is a result of the 
high value vegetable, fruit and nut crops produced in the top three states, California, Washington and Oregon (Carusi, Gurda, McNair, Pfeiffer, \& Silva, 2015, p. 6).

\section{Ownership in land using for organic farming}

The data analysed in this research showed that in total 78\% (457) farmers said that they were using own land for organic agriculture followed by $14.3 \%$ (84) had taken land in rent, $6.8 \%$ (40) said that they used own land and some land was taken in rent also and 0.9\% (5) had used others' land. Other means unused public land and land of relatives. District wise, in total 3.9\% (23) farmers of Kathmandu had their own land using for the organic agriculture followed by 27.5\% (161) of Lalitpur, 7.2\% (42) had Bhaktpur and 39.4\% (231) of Dhading. Similarly, comparatively, high number (8\%) of farmers of Bhaktpur district had taken the land in rent. Sometimes, the farmers has to face the loss from the selling of organic product in rented land because they have to pay the rent and bear the cost of investment in seeds, labours, transportation.

Table 2: Ownership in land using for organic farming

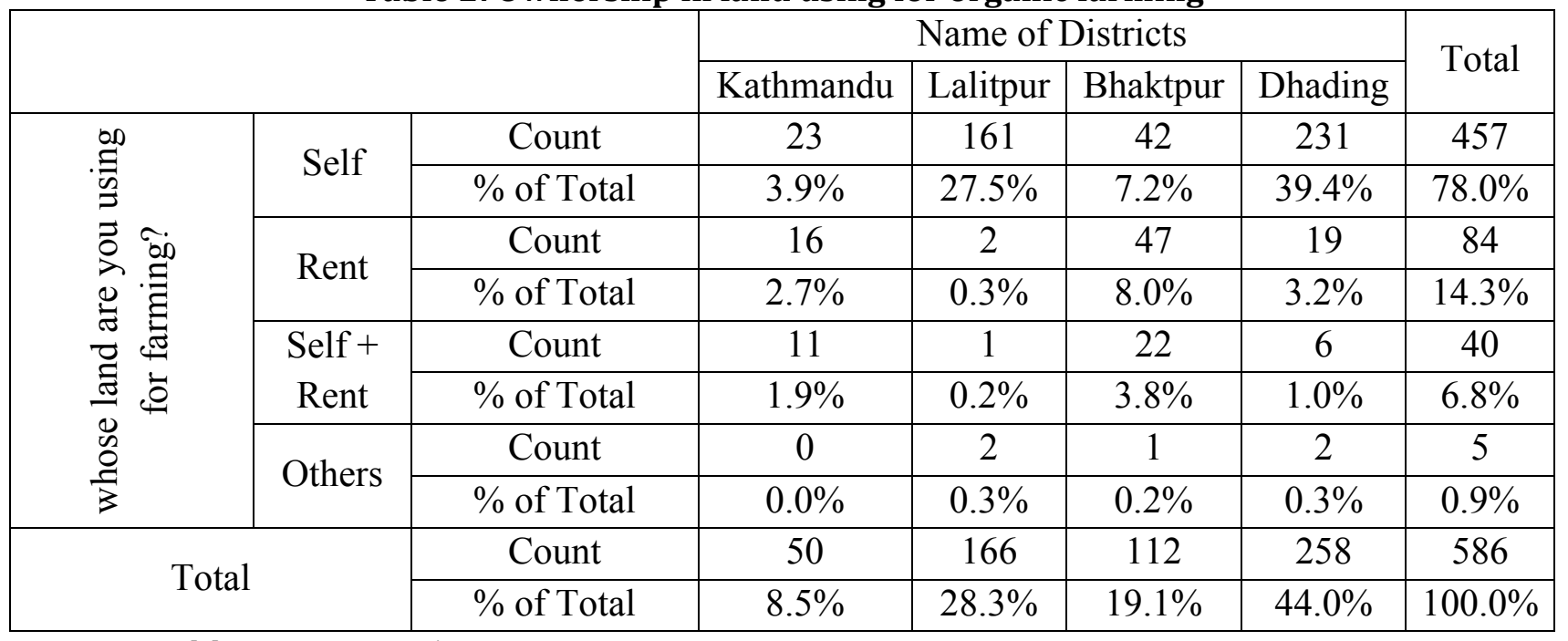

Source: Field Survey, 2015

\section{Annual income of farmers from organic farming}

The primary data collected from the farmers reported that the range of annual income was NPR 2000/- to 30, 00,000/-. The mean annual income was NPR 1, 27,813.11. Average income of farmers was seemed good which can support to manage the basic needs of their family.

Table 3: Annual income of farmers from organic farming

\begin{tabular}{|c|c|c|c|c|c|}
\hline \multicolumn{7}{|c|}{ Descriptive Statistics } \\
\hline & $\mathrm{N}$ & Minimum & Maximum & Mean & Std. Deviation \\
\hline Annual Income & 511 & 2,000 & $30,00,000$ & 127813.11 & 277648.291 \\
\hline
\end{tabular}

Regarding the income of organic agriculture, there is some misconception among those farmers who are not doing the organic agriculture that they will have to bear the loss from the organic agriculture. But Pharsuram Acharya, Owner of Annapurna Organic Agricultural Industry was not ready to accept the misconception of loss of organic agriculture. He said, "Organic agriculture itself is sustainable system so it is totally misconception that farmers have to bear loss from organic agriculture. If farmers get the access on market and get the good price of product then organic agriculture support to increase the socio-economic status of farmers." 
United State Department of Agriculture has reported that the consumer demand for organically produced goods has shown double-digit growth during most years since the 1990s, providing market incentives for U.S. farmers across a broad range of products. Organic products are now available in nearly 3 of 4 conventional grocery stores, and often have substantial price premiums over conventional products. Organic sales account for over $4 \%$ of total U.S. food sales, though organic products account for a much larger share in some categories. Certified organic acreage and livestock have been expanding in the United States for many years, particularly for fruits, vegetables, dairy, and poultry. The U.S. Department of Commerce began adding codes for selected organic products to the U.S. trade code system in 2011, and the tracked value of organic imports and exports has been increasing (United State Department of Agriculture, 2015).

The importance of organic agriculture is highlighted in previous study in relation to their contribution in economic development of farmers. A previous study has stated that 'Money can grow on trees, and so can jobs -- if those trees are organic'. The report of Farm Bill and beyond had highlighted the importance of organic farming to increase the job opportunity and income sources. Organic agriculture can have a strong positive impact on the U.S. economy and is good for job creation, says a new study by Organic Farming Research Foundation (OFRF) (Redell, September 30, 2011).

\section{ANOVA of total income}

This study was conducted among the 4 districts of central hill of Nepal so the study analysed the analysis of variance of income among the 4 districts. The finding of ANOVA showed that there was significant difference $(F=13.901 \& \mathrm{P}=.000)$ between and within groups of district regarding the annual income of organic agriculture at $95 \%$ confidence interval.

Table 4: ANOVA of total income

\begin{tabular}{|c|c|c|c|c|c|}
\hline \multicolumn{7}{|c|}{ ANOVA of Total Income } \\
\hline & Sum of Squares & df & Mean Square & F & Sig. \\
\hline Between Groups & 2988124199092.684 & 3 & 996041399697.561 & 13.901 & .000 \\
\hline Within Groups & 36327048203059.960 & 507 & 71650982649.033 & & \\
\hline Total & 39315172402152.640 & 510 & & & \\
\hline
\end{tabular}

Source: Field Survey, 2015

Organic agriculture can be beneficial for farmers, although the transition period is often financially difficult. The organic sector accounted for less than $3 \%$ of total food sales in the US in 2005 , but growth is strong and is projected to remain well above $10 \%$ per year. This strong growth has attracted the attention of large corporations, from processors and distributors such as Kraft and General Mills to retailers such as Wal-Mart ( University of Wisconsin-Madison, 2014).

\section{District wise Multiple Comparisons of income}

The F-test showed the significant difference between the districts so the study also analysed the multiple comparisons of individual districts to know the difference between the two districts. The data presented in the table no. 5 Showed that there was significant difference between the Kathmandu and Lalitpur district regarding the annual income at $\mathrm{P}=.007$ at $95 \%$ confidence interval. Similarly, there was highly significant difference between the Lalitpur and Bhaktpur district regarding the annual income at $\mathrm{P}=.000$ at $95 \%$ confidence interval. The data also presented the significance difference between the Bhaktpur and Dhading at $\mathrm{P}=.000$ and 
Dhading and Kathmandu at $\mathrm{P}=.022$. but there was no significant difference between the Lalitpur and Dhading as well as Bhaktpur and Kathmandu.

The three districts (Kathmandu, Lalitpur and Bhaktpur) districts are located in within the Kathmandu valley. There are more similarity in the climate, geographical structure, development and distribution of population. Though, the annual income was significantly difference between Kathmandu and Lalitpur and Lalitpur and Bhaktpur. The reasons were the access on market, quantity and quality of productions, numbers of conscious consumers and purchasing capacity of consumers. Kathmandu district is highly populated than the Lalitpur and Lalitpur is highly populated than the Bhaktpur so it makes the difference in the selling of products which finally effect in the income of farmers.

Similarly, analysis showed that within Kathmandu valley also, there was no difference between the Bhaktpur and Kathmandu. The annual income was found similar between these two districts. Bhaktpur is famous for the agriculture products and Kathmandu is the main market for selling the goods. Bahaktpur can produce high amount of production because of the availability of adequate agriculture land and Kathmandu has capacity to consume much production so income level of farmers of Bhaktpur and Kathmandu may be similar.

Table 5: District wise Multiple Comparisons of income Multiple Comparisons

\begin{tabular}{|c|c|c|c|c|c|c|}
\hline \multicolumn{7}{|c|}{ Multiple Comparisons } \\
\hline \multicolumn{7}{|c|}{ Dependent Variable: Annual income of organic farming } \\
Bonferroni
\end{tabular}

Source: Field Survey, 2015

\section{Regression analysis}

From the analysis of linear regression, it is found that the R2 value is .161 which means that demographic variables (address, age, sex, education, year of experience, total organic land of individual farmer) only explain $16.10 \%$ of the variation in the Annual income of organic farming (dependent variable). The adjusted R2 value is .150 which means that the different demographic variables contributed only $15 \%$ in annual income of organic farming. The remaining $85 \%$ were contributed by other factors which are not included in this study.

The regression analysis on all six demographic variables were found significant at $\mathrm{p} \leq 0.05$ (.000), at $F=13.901$ to total annual income of organic farming. However, it was found out that only two variables were significant which have p-value $\leq 0.05$, namely educational status and total agricultural land using by the farmers. Rest four variables i.e. Address, age, sex and year of experiences of respondents were not significant to total income since the p-value of each 
was $.151, .968, .387$ and .311 respectively. We may conclude by saying that at least two demographic variables, namely educational status and total organic agriculture land of respondents has impact on total income of organic agriculture.

Table 6: Regression analysis

\begin{tabular}{|c|c|c|c|c|c|c|c|c|c|}
\hline \multicolumn{10}{|c|}{ Model Summary } \\
\hline \multicolumn{2}{|c|}{ Model } & \multicolumn{2}{|c|}{$\mathrm{R}$} & R Square & \multicolumn{3}{|c|}{ Adjusted R Square } & \multicolumn{2}{|c|}{ Std. Error of the Estimate } \\
\hline & 1 & \multicolumn{2}{|c|}{$.401^{\mathrm{a}}$} & .161 & \multicolumn{3}{|c|}{.150} & \multicolumn{2}{|c|}{258329.943} \\
\hline \multicolumn{10}{|c|}{$\begin{array}{c}\text { a. Predictors: (Constant), land size, Edu, year of experience, Sex of respondents, Age of } \\
\text { respondents, Name of districts }\end{array}$} \\
\hline \multicolumn{10}{|c|}{ Coefficients $^{\mathrm{a}}$} \\
\hline \multirow{2}{*}{\multicolumn{3}{|c|}{ Model }} & \multicolumn{2}{|c|}{$\begin{array}{l}\text { Unstandardized } \\
\text { Coefficients }\end{array}$} & \multirow{2}{*}{$\begin{array}{c}\begin{array}{c}\text { Standardized } \\
\text { Coefficients }\end{array} \\
\text { Beta }\end{array}$} & \multirow{2}{*}{$\mathrm{t}$} & \multirow{2}{*}{ Sig. } & \multicolumn{2}{|c|}{$\begin{array}{l}95.0 \% \text { Confidence } \\
\text { Interval for B }\end{array}$} \\
\hline & & & B & Std. Error & & & & $\begin{array}{l}\text { Lower } \\
\text { Bound }\end{array}$ & $\begin{array}{l}\text { Upper } \\
\text { Bound }\end{array}$ \\
\hline \multirow{7}{*}{1} & \multicolumn{2}{|c|}{ (Constant) } & -84588.374 & 91345.626 & & -.926 & .355 & -264064.019 & 94887.271 \\
\hline & \multicolumn{2}{|c|}{$\begin{array}{l}\text { Name of } \\
\text { districts }\end{array}$} & 18397.046 & 12805.059 & .068 & 1.437 & .151 & -6762.300 & 43556.391 \\
\hline & \multicolumn{2}{|c|}{$\begin{array}{l}\text { Age of } \\
\text { respondents }\end{array}$} & -44.816 & 1112.280 & -.002 & -.040 & .968 & -2230.221 & 2140.589 \\
\hline & \multicolumn{2}{|c|}{$\begin{array}{l}\text { Sex of } \\
\text { respondents }\end{array}$} & -23456.135 & 27084.860 & -.039 & -.866 & .387 & -76672.396 & 29760.126 \\
\hline & \multicolumn{2}{|c|}{ Education } & 41286.061 & 8040.872 & .242 & 5.135 & .000 & 25487.377 & 57084.744 \\
\hline & \multicolumn{2}{|c|}{$\begin{array}{c}\text { Year of } \\
\text { experience }\end{array}$} & -1957.294 & 1931.326 & -.048 & $\begin{array}{c}- \\
1.013\end{array}$ & .311 & -5751.959 & 1837.370 \\
\hline & \multicolumn{2}{|c|}{$\begin{array}{l}\text { Total organic } \\
\text { agriculture } \\
\text { land }\end{array}$} & 14860.080 & 2072.483 & .319 & 7.170 & .000 & 10788.071 & 18932.089 \\
\hline
\end{tabular}

Source: Field Survey, 2015

\section{CONCLUSION}

In reality, organic agriculture is not new phenomena in Nepal since the conventional farming is also followed the similar system of organic agriculture. However theoretically, it makes the different between the conventional and organic agriculture. In Nepal, conventional farming has its own traditional way of farming and in the recent days excessive use of chemical fertilizers to increase productivity giving less care on the possible risk on health of consumers. There has not been any trademark to recognize the conventional agriculture but organic farming has certain rules, principles and trademark which ensure the quality of organic agriculture. The same trademark also ensures the price of production. The study found that the annual income of farmers was better than the simple labour work. Social status of farmers was also uplifted because of the better economic status. They shared that they could easily manage the health and education of their children and also manage the daily expenditure of house. As organic farming has been attracting youths gradually, which is being seen as supportive to retain youths in agriculture and look for internal livelihoods options rather than going for international labour migration. . The data of this research showed that involvement of youth is 
increasing in organic agriculture which can support to sustain it in long run. There is need of educated person in organic field because the data also showed that there was significant effect of education to determine the income of farmers. Distribution of income was significantly difference between the districts because of the quality and quantity of production and their access on organic market. Land size had significant effect in income of farmers so there is need to increase the size of organic land to increase the level of income. Level of consumers' awareness and their purchasing capacity also play the vital role to determine the income of organic agriculture. So, it is also recommended to concerned organization to launch the consumers' awareness program. Government should encourage the farmers to expand their organic business by supporting to manage the organic market. Auction market can be one strategy to protect the farmers from the loss of their organic productions.

\section{Bibliography}

University of Wisconsin-Madison. (2014). Retrieved from University of Wisconsin-Madison: http://www.cias.wisc.edu/curriculum/modV/secd/modVsecD.htm

Agri statistics Section. (2011/2012). STATISTICAL INFORMATION ON NEPALESE AGRICULTURE. Agri-Business Promotion and Statistics Division, Ministry of Agricultural Development. Kathmandu, Nepal: Government of Nepal. Anjana Malla Pradhan, C. B. (2015, April ). An Alternative Source of Livelihood: Socio-Economic Analysis of Organic Vegetable Growing in Nepal: A Case Study. International Journal of Science and Research (IJSR), 4(4), 924928.

Canadian Organic Growers. (2011). Organic Field Crop Handbook. Ottawa, ON. K1Z 7K4: Canadian Organic Growers.

Carusi, C., Gurda, A., McNair, R., Pfeiffer, A., \& Silva, E. (2015). ORGANIC AGRICULTURE IN WISCONSIN 2015 STATUS REPORT. Agriculture Department. UW-Madison Center for Integrated Agricultural Systems and the Wisconsin Department of Agriculture, Trade and Consumer Protection.

Delbridge, T. A., Coulter, J. A., King, R. P., Sheaffer, C. C., \& Wyse, D. L. (2011, September 1). Economic Performance of Long-Term Organic and Conventional Cropping Systems in Minnesota. Agronomy Journal.

Helga Willer, J. L. (2014). The World of Organic Agriculture 2014: Summary. Switzerland: Research Institute of Organic agriculture (FiBL), Frick, International Federation of organic movement (IFOAM), Bonn.

One Country. (2013). Retrieved September 7, 2015, from Bahá'í International Community: http://www.onecountry.org/story/importance-agriculture

Redell, C. (September 30, 2011). Organic Farming Could Grow Even More Jobs with Better Policy Support. USA: GreenBiz Group Inc./http://www.greenbiz.com/news/2011/09/30/organic-farming-grow-more-green-jobsbetter-policy-support.

United State Department of Agriculture. (2015, June 2). Retrieved December 1, 2015, from United State Department of Agriculture: Economic Research Service: http://www.ers.usda.gov/topics/natural-resourcesenvironment/organic-agriculture.aspx

University of Wisconsin. (2014). Retrieved October 1, 2015, from University of Wisconsin: http://www.cias.wisc.edu/curriculum/modV/seca/mod_v_seca.htm

USAID. (2015, July 24). Home: USAID. Retrieved Octomber 1, 2015, from USAID:

https://www.usaid.gov/nepal/agriculture-and-food-security 